\title{
Algunos comentarios y reflexiones a cuatro meses de la llegada de la pandemia a Chile
}

\author{
Four months after the arrival of the pandemic in Chile: \\ Some comments and reflections
}

\author{
Guillermo Lema Fuxman ${ }^{1}$
}

140 a sido efectivamente una tragedia, y como ocurre en estas situaciones, nadie, ningún país estaba preparado. Estados Unidos con más de 140.000 fallecidos, Brasil 60.000, Italia más de 40.000 y los números lamentablemente siguen subiendo.

Rebrote en algunos países: Francia, España, Reino Unido, Corea, Japón, Australia y otros. Varias explicaciones para ello: ¿La estrategia de manejo de la pandemia fue inadecuada? ¿El virus mutó? ¿Los sistemas sanitarios se relajaron y abrieron los confinamientos antes de lo deseado? ¿El virus no provoca la inmunidad de meses o años como fue planteado al comienzo? ¿Todas? Pero quizás una de las cosas más graves ha sido la falta de conciencia de la población de que esto no es un "resfriadito" como dijo un presidente vecino (ya COVID-19 +) o solo una hebra de RNA como dijo un colega chileno. Hace pocos días apareció la noticia del aumento de casos en algunos lugares de Estados Unidos. Uno de ellos, Arizona. Nadie se explicaba muy bien lo que pasaba. Finalmente, se supo que grupos de universitarios se reunían (muchos), en salas pequeñas a beber. Uno de los presentes era COVID-19 +. El propósito era, entregar un "premio" al primero de los otros que se contagiaba... PLOP. Desde ahí surgieron polos de contagio que han convertido este estado, generalmente tranquilo, en uno de los con mayores números de pacientes contagiados en los últimos días. Este "juego" se ha repetido en otros lugares: Alabama, Texas, el Estado de Washington, y otros. No sé si esta modalidad de "fiesta" esté ocurriendo en Chile, pero lo que sí sabemos es que las fiestas, con grandes números de asistentes y sin ningún tipo de protección, siguen en muchas ciudades del país.

He mencionado que no soy experto en virología, ni menos en comportamiento de estas pandemias, por lo tanto, los números que se nos presentan, son difíciles para mí analizarlos con la rigurosidad que se requiere. Yo creo en estos datos, creo en las autoridades actuales que los presentan. Sería una aberración el que se mintiera a la población con un tema tan sensible. Definitivamente creo que no. No sé si la estrategia actual: identificar, trazar, aislar, sea la correcta. Creo que la asesoría de expertos es una de las mejores que tenemos, y mejor aún, de distinto signo político. Disponemos de expertos en salud pública, en epidemiología, en infectología, virología. De ellos debiéramos poder tener ideas, sugerencias y caminos para enfrentar esta pandemia, aún muy lejos de ser controlada.

Preocupa las constantes apariciones en TV, en noticiarios y también en programas de farándula, de colegas y otros entregando "soluciones farmacológicas" para el manejo de este cuadro clínico. Hasta ahora, quizás el uso de corticoides, de plasma, son probablemente las únicas terapias que han aparecido como promisorias en este contexto clínico. El resto todavía está por verse. ¿Vacunas?, aún faltan meses y meses, hasta poder disponer de alguna que tenga efectos beneficiosos, sin efectos negativos propios de un producto farmacológico preparado "contra el tiempo" Las redes sociales, tan útiles en otros momentos, han

1 Profesor Titular, División de Anestesiología, Pontificia Universidad Católica de Chile, Universidad Austral de Chile.

Fecha de recepción: 5 de septiembre de 2020

Fecha de aceptado: 5 de septiembre de 2020

\section{ORCID}

https://orcid.org/0001-9134-2169

Correspondencia:

gmolema@gmail.com 
aportado muy poco en el correcto análisis de lo que es "cierto" vs lo que es "paja molida".

Esperemos resultados fidedignos de las Universidades, de Centros de estudios idóneos, del Ministerio de Salud, del ISP, que nos entreguen recomendaciones claras acerca de lo que debemos usar en beneficio de los pacientes.

¿Faltó equipamiento en los hospitales y clínicas?, quizás. Durante muchos meses se mencionó que los ventiladores mecánicos eran la piedra de tope para enfrentar estos casos. Es cierto, son importantes. Sin embargo, lo más crítico es el personal. En todos los lugares faltó mucho personal idóneo, pese a la asesoría que los expertos entregaron. Un ventilador mecánico no es nada sino tiene alguien experto en diferentes modalidades de ventilación que cada paciente requiere.

Muchos hospitales y clínicas debieron recurrir a profesionales no intensivistas para manejar ciertas áreas críticas. Los anestesiólogos han jugado un rol muy importante en esta cobertura. El hospital UC, donde trabajo, dispuso de más de 40 anestesiólogos solo para cubrir áreas de intensivo con pacientes COVID-19. Gran pega. Sospecho que en otros lugares ha sido lo mismo.

¿Superaremos esta crisis? creo que sí. Pero como mencioné recientemente, nuestra medicina cambiará, nuestro manejo de situaciones clínicas también. Deberemos planificar con mayor acuciosidad y precocidad el enfrentamiento de enfermedades que aparezcan en otros confines del mundo. Querámoslo o no en algún momento nos llegará.

¿Alguien honestamente pensó que esta infección aparecida en un mercado de una ciudad de China llegaría a Chile y produciría esta catástrofe?

Preparémonos: equipamiento humano entrenado, estrategias de manejo idóneas, materiales e insumos adecuados en número e idealmente en cantidad, interacción entre los diferentes actores para saber y entender lo que pasa. Las videoconferencias ya se han convertido en elementos importantes para interactuar y recibir informaciones desde nuestro lugar de trabajo, así como también de otros expertos de la comunidad científica... en tiempo real. Llegaron para quedarse.

No hay excusa para no saber, para no aprender, para no consultar.

¿Estuvimos preparados? En esta ocasión nadie, tampoco aquellos países con gigantescos recursos destinados a salud. Sin embargo, creo que hemos aprendido, hemos reconocido abiertamente nuestras deficiencias y errores, y al mismo tiempo nuestras posibilidades de mejorar. No esperemos que la próxima catástrofe esté a la vuelta de la esquina. Para una próxima oportunidad, tengamos todo listo.

Como mencioné, partiendo de cero y contra el tiempo, reinventémonos. Podemos hacerlo.

¿Hay recursos? Seguramente se dirá que no. Lo que pasa es que hay que priorizar en qué ocupar lo que tenemos. La salud es prioritaria. Esta pandemia ha desnudado entre otras, las falencias que tenemos en esta área. 